SNSから見る北海道新幹線開業後の地域・拠点に対 する関心構造の変化

\begin{tabular}{|l|l|}
\hline 著者 & 浅田 拓海, 鈴木 貴文, 有村 幹治 \\
\hline 杂隹誌名 & 土木学会論文集D3 (土木計画学) \\
\hline 巻 & 74 \\
\hline 号 & 5 \\
\hline 発ージ & I_547-I_554 \\
\hline 発行年 & 2018 \\
\hline URL & ht t p: //hdl . handl e. net /10258/00010244 \\
\hline
\end{tabular}




\title{
SNSから見る北海道新幹線開業後の 地域・拠点に対する関心構造の変化
}

\author{
浅田 拓海 1 ・鈴木 貴文 2 ・有村 幹治 $^{3}$ \\ 1正会員 室蘭工業大学助教 大学院工学研究科（广050-8585 室蘭市水元町27-1） \\ E-mail: asada@mmm.muroran-it.ac.jp \\ ${ }^{2} \mathrm{HRS}$ 株式会社 環境防災部（干047-0005 小樽市勝納町8-39） \\ E-mail: ta.suzuki@h-r-s.co.jp \\ 3 正会員 室蘭工業大学准教授 大学院工学研究科（干050-8585 室蘭市水元町27-1） \\ E-mail: arimura@mmm.muroran-it.ac.jp
}

\begin{abstract}
本研究では, 北海道新幹線開業前後におけるTwitterデータを用いて, 地域・拠点ワードの発生増加やそ れらの関連性を分析し, 人々の関心構造の変化を明らかにした。 まず, ワード個別に発生数を求め, 開業 後に関心が増加した地域や拠点を抽出した。次に, 函館や道内外に関寸るワードの発生増減の類似性から ユーザを関心増加層, 関心低下層, 無変化層の3つの層に類型化した，最後に，ユーザ層毎に，地域・拠 点ワードの共起構造を分析し, 次数中心性指標から, 関心先の関連性を定量的に評価した。 その結果, 個 別の発生数では抽出困難であったワードが浮上し, 特に, 関心増加層ではそれが顕著であること, 開業後 にユーザの関心先が大きく広がることを明らかにした。
\end{abstract}

Key Words : Twitter, round tourism, interest, co-occurrence structure, centrality measures

\section{1. はじめに}

現在，我が国では，観光立国の実現に向けた施策が積 極的に推進されている，最近では，成長著しいアジア諸 国をはじめとする観光需要の取り込办により，訪日外国 人観光客数が著しく増加している状況にある. 北海道に おいては, 食, 景観, 温泉, アウトドアなど様々な地域 の魅力を求めて, 国内外からの観光客数がシーズンを通 して増加している. 2016年 3 月には，北海道新幹線が開 業し，特に，終着駅のある函館エリアでは，観光客の入 り込みが順調に増加していることが報じられている。 こ のような大型の交通政策，整備は，ヒト・モノの流れを 変えるだけではなく, 沿道・沿線上の地域や周辺拠点な どに対する人々の関心にも影響を及ぼしているであろう. 例えば，本研究で対象とする北海道新幹線について，そ の開業後で，どのような人たちが，どのような地域や観 光拠点に関心を持つようになったのか，さらには，関心 先の関連性がごのように変化したのか, このような人々 の「関心構造」の変化を捉えることができれば，当該事 業が人々の心理側面に及ぼした影響を評価することがで きる.また，これらの結果は，今後の観光拠点や周遊ル 一トの検討などへの有用な情報となり得る.
観光に関する関心や意識の把握については, 古くから アンケート形式の調査が採用されて来たが，その収集範 囲が時間的，空間的に限られるため，広域的なエリアを 対象とすること，そして，長期に渡る観測は難しい，近 年では, いわゆる人の関心のビッグデータとして, 任意 の時空間対象のデータを扱うことができるTwitterや FacebookなどのSNSのデータ活用による都市や観光関連 の分析事例が報告されている(1)44. 土木計画分野におい ても，まちづくりや観光に加え，防災，交通システムな ど，様々な対象，アプローチが報告されている5)-8゙， 大型の施策，交通整備の影響について，長期的な期間に 渡る人々の関心の変化を分析した事例は見受けられない.

一方，ネットインフラの充実化，SNSの利用率の高ま りから，今後は，谷口らが提唱するように，SNSのよう なサイバー空間上にある個人の投稿データにも目を向け た「ネットコンシャス」なまちづくり9も重要となろう. 谷口らは，都市名やそれに関するキーワードやタグ等の 出現頻度の季節・時間変動, さらには, 関心先と関心事 の関係などから，都市や観光拠点の分析を行うとともに， SNSデータの有用性を示している界 ${ }^{11)}$. しかしながら， これらの研究のような「場」を対象としたSNSの分析で は，対象ワードを個別に集計するケースがほとんどであ 
り，ワードの共起構造から，人々の関心先となる地域， 拠点の関連性を明らかにした事例は少ない.

観光先として関心が持たれる地域や拠点は，単独では なく複数が結びついて連想され，時空間的な制限の中で その幾つかは実際の旅行先となる。したがって，このよ うな関心先のつながりを把握することは，周遊ルート提 案，さらには周遊の長期化を図る上で極めて重要である. SNSでは，関心のある地域や観光拠点についてコメント や写真，場に関するタグや位置情報などが投稿される場 合が多い. このデータを用いて, 関心先の共起構造を分 析することで，それらの関連性を把握することができる. 著者らの先行研究では, 室蘭市を対象に, Twitterのコメ ントから地域や観光拠点のワード（以下，地域・拠点ワ ード）を検出し，ユーザー毎にそれらを結びつけ，その 共起構造から人々の関心先のつながりを把握した ${ }^{22}$.

本研究では, 北海道新幹線開業前後のTwitterデータを 用い，地域・拠点ワードの共起構造を分析することで, 開業後における人々の関心構造の変化を明らかにする. 具体的には以下の手順で分析を行う。まず，開業前後に おける地域・拠点ワードの発生数を個別に比較し，開業 後に関心が増加するワードを抽出する. 次に, ワードの 発生の類似性でユーザを類型化し，函館エリアへの関心 が増加するユーザがどの程度いるのかを確認する，最後 に, ワードの共起構造を分析し, 関心先のつながりが開 業後にどの程度広がるのかを明らかにする．さらに，こ の共起構造を基に, 将来的に対象地域一の関心が増加寸 るユーザや地域，拠点を予測する方法について検討する.

\section{SNSデータの概要}

SNS には，Twitter，Facebook，Instagram，LINE などが あり，昨今では，用途や利用シーンに応じて複数の SNS を使い分けるユーザも増えている. 代表的な SNS の年 代別利用者率 13)を図-1 に示寸．利用率の高い Youtubeや LINE は, 主に, 動画の配信や視聴, 個人間の連絡など に使用されるケースが多い.コメントや写真の投稿型と しては, Facebookや Twitterがあり, 最近では Instagramや Google+の利用者も増加している，この中で，Twitter ${ }^{(4)} は ，$ 30 代以上の利用率は比較的少ないものの, 日常生活に おける関心を「つぶやき」として気軽に投稿でき，観光 や地域に対するコメントが投稿される場合もある。 また, API (Application Programming Interface) やデータ購入サー ビスを利用することにより，大規模なコメントデータを 入手可能である. 以上の点から, 本研究では, Twitter に 着目し，そのコメントデータを用いた分析を行った.

まず，北海道新幹線開業による波及効果が大きいと考 えられるエリアを設定し，それに含まれる市町村名を

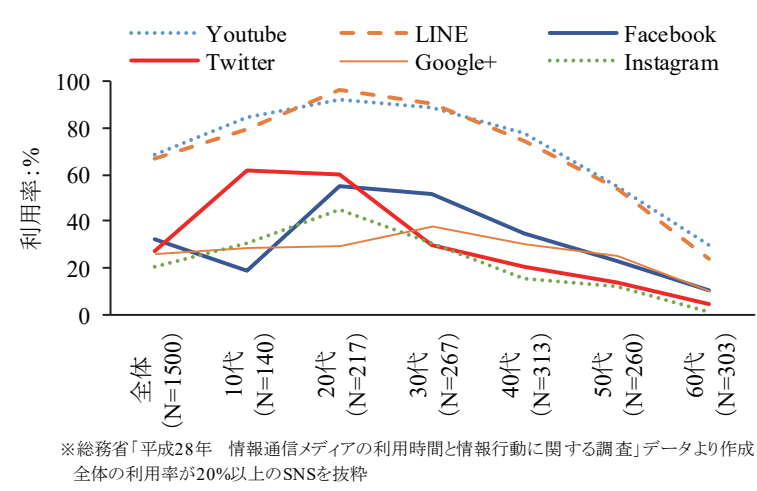

図-1 SNS の利用率比較 ${ }^{13)}$

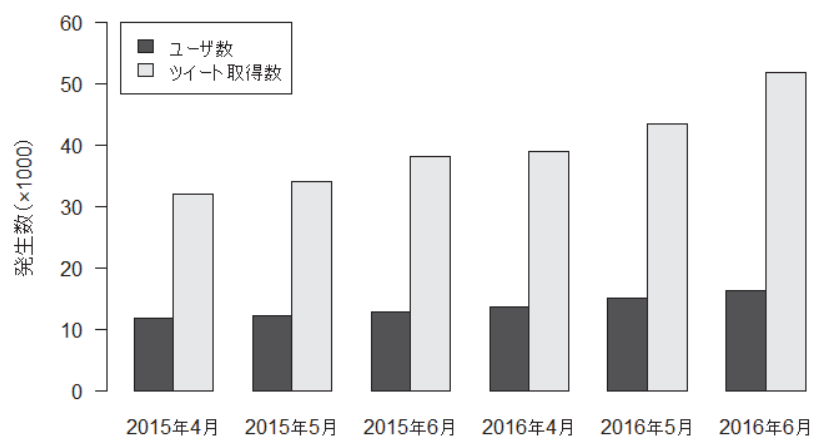

図-2 月別のツイート取得数とユーザ数

「函館地域ワード」として設定した。このエリアは，新 幹線終着駅である $\mathrm{JR}$ 新函館北斗駅を中心とした半径 $100 \mathrm{~km}$ の範囲に限定した。この範囲円の大きさは, 渡 島・檜山地方の市町村が全て含まれるように設定してい る. 対象は, 長万部町, 八雲町, 森町, 鹿部町, 七飯町, 函館市, 北斗市, 木古内町, 知内町, 福島町, 松前町, 今金町, せたな町, 奥尻町, 乙部町, 厚沢部町, 江差町, 上ノ国町, 蘭越町, 寿都町, 二セコ町, 真狩村, 喜茂別 町，留寿都村，黑松内町，島牧村，伊達市，豊浦町，洞 爺湖町, 壮睯町, 白老町, 登別市, 室蘭市の 33 市町村 となる. Twitter 公式ページから, コメントにこれらの何 れかを含む投稿を検索，取得した．得られたデータには， ユーザのスクリーンネーム，コメント，投稿日時が収録 されている. また，検索対象期間は，2015 年の 4〜6月

(開業前) および2016年の 4 6月（開業後）である.

個人ユーザによる自発的なコメントを分析対象とする ため, ニュースや BOT（特定の時間に特定の内容を自 動的に投稿する仕組み），交通情報や行政や商業施設， 広告等のユーザ，また，リツイートのデータは除外した。 ただし，この処理を行っても，分析対象外のユーザやコ メントがノイズとして残っている可能性がある. しかし ながら, 検索方法, ユーザ・コメントの除外条件は統一 されており，ノイズが入る確率は期間によってほとんど 変化しないと考えられることから, 月や年の比較による

「変化」を捉えることは可能と判断した. 

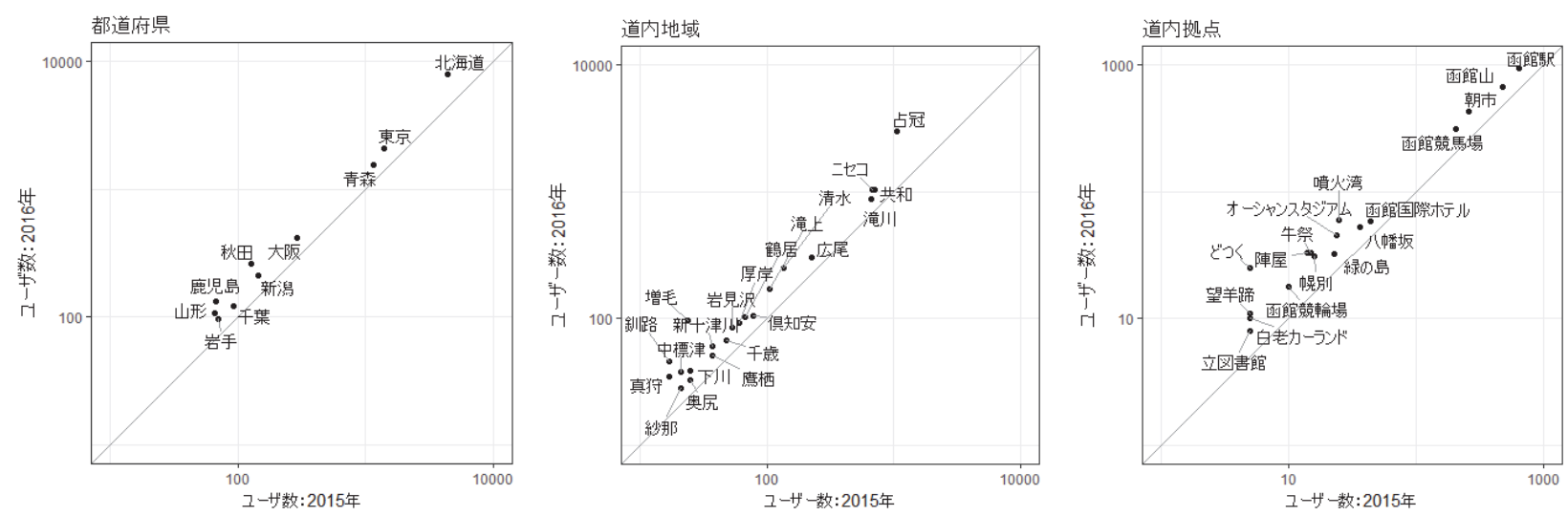

図-3 ユーザー数の年比較
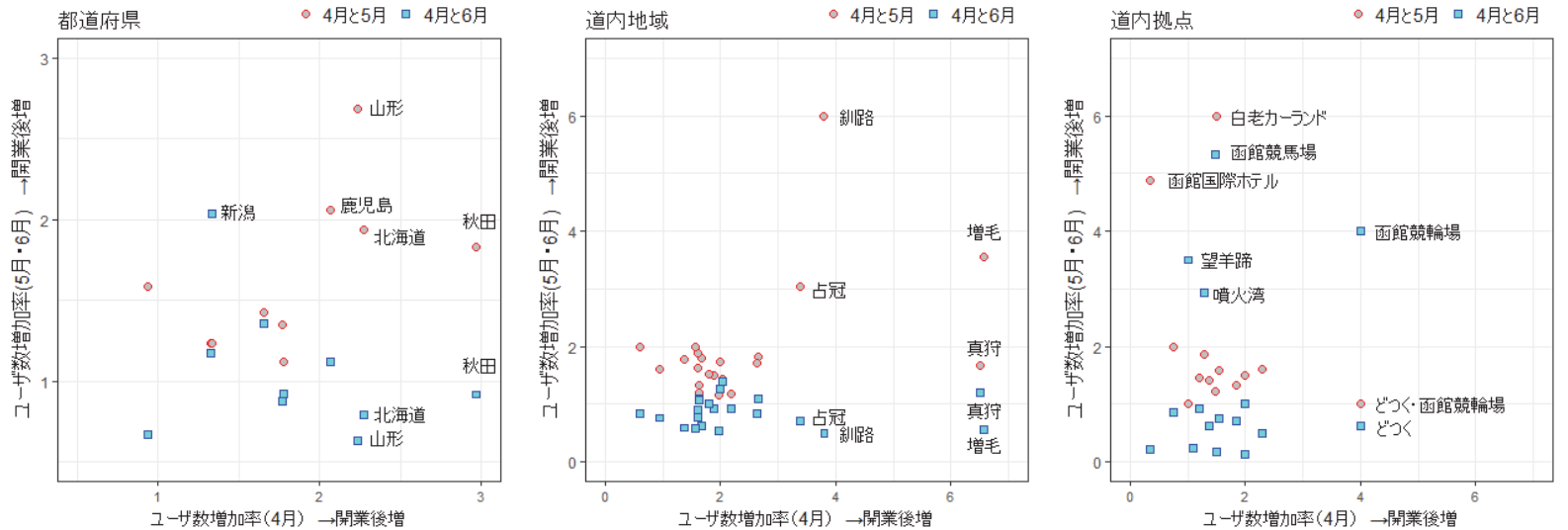

図-4 ユーザ増加率の月比較

各検索ワードを発生させたユーザー数（ユニーク数） およびッイート取得数を図-2 に示す．両者はともに 2015 年 4 月から 2016 年 6 月にかけて増加しており, 開 業後の方が多いことが分かる．なお，全期間におけるユ ーザのユニーク数は, 23,704 人であった.

\section{3. 北海道新幹線開業後における地域・拠点ワー ド発生量の変化}

上記の函館地域ワードから得られたコメントには, 他の地域や，より詳細な観光拠点が共にコメントされて いる. そこで，全国の都道府県名に加え，道内の市町村 名および観光拠点をWEB サービス等で収集し，これら の地域・拠点ワードを「都道府県（47 ワード）」「道 内市町村 (179 ワード)」「道内拠点 (2,032 ワード)」 の3つの空間レベルに区分し，各ワードを発生させたユ 一ザ数（以下，ユーザ数）を集計した. 北海道新幹線開 業前後の 2 期間におけるユーザ数の関係を図-3に示す. また, 各ワードの発生量の細かい変化が分かるように, 2015 年から 2016 年へのユーザ数の増加率を月別に求め た. 4 月と 5 月， 4 月と 6 月のそれぞれの関係を重叔て
プロットしたものを図-4に示す，なお，ここでは，開 業後に関心が増加した地域，拠点を把握することを目的 とするため，両図ともに，ユーザ数の増加率が 1.2 倍以 上となるワードのみプロットした.

都道府県レベルでは，図-3 に示すように，「北海 道」が最も多く, 次いで, 「東京」「青森」が 1,000 10,000 規模のユーザからコメントが発生されている，発 生数が 100〜500 程度と少ない範囲では，「山形」「岩 手」「秋田」などの東北地方があり, 特に, 「秋田」に 関しては開業後の増加が大きい. 遠くは「大阪」，「鹿 児島」の発生も多く, 開業後に増加した. 図-4 のユー ザ増減率で見ると，「山形」「秋田」「鹿児島」は， 「北海道」と同様な傾向を示し， 6 月には低下寸るもの の, 開業直後の 4,5 月では大きく増加している. これ らの道外のワードは, 函館地域ワードとともにコメント されている. 北海道新幹線開業によって, これらの道外 地域からのアクセス性が高まり, 道南・道央地域一の関 心が高まったものと考えられる，なお，「鹿児島」につ いては，そのコメントを調べると，新幹線ルートとして， 北海道と（新函館北斗駅） と鹿児島（鹿児島中央駅）が 繋がったことによる歓喜のコメントが見られた。

道内市町村レベルでは，図-3 に示したように，函館 
地域ワードである道南・道央地域の増加はほとんど見ら れなかった．この原因については，次章で検討する。一 方，それ以外の道内地域，特に，図-4にあるように，

「真狩」「増毛」「占冠」「釧路」などは，4，5 月に 開業後の増加が見られた. 6 月には開業前と同等に戻る ことから, 関心の向上は一時的なものであるが，北海道 新幹線開業によって, 道内の様々な地域への関心が広が った，またはこれらの地域のユーザからの関心が増加し たと考えられる.

道内拠点レベルでは，「函館山」「朝市」「噴火 湾」「望羊蹄（レストラン：洞爺湖町）」など，検索ワ 一ドの道南・道央地域にある拠点で増加が見られた。一 方，函館地域ワード以外の地域の拠点は，両時点のユー ザ数が少ないのは必然的ではあるが，開業後の増加に大 きな変化が見られなかった. このことから，北海道新幹 線開業による観光拠点への関心の広がりは, 道南・道央 地域内に留まっているものと推測される. ただし，4月 よりも 5, 6 月に増加傾向を示寸拠点が多いことから, それ以降にじわりじわりと関心が増加する拠点も出現す る可能性もある. 長期的なモニタリングが必要であるた め, これについては今後の課題としたい.

\section{4. 地域・拠点ワードの共起構造分析}

第3章では，地域・拠点ワードを個別に集計し，北海 道新幹線開業後に発生数が増加するワードを抽出した. しかしながら，このアプローチでは，地域・拠点間のつ ながりや関係性を見ることはできない，また，データの 中には，そもそも函館や北海道への関心が無いユーザも 含まれており, 関心の増加が捉えにくくなっている可能 性がある. そこで, 本章では, 地域・拠点ワードの増減 パターンからユーザをクラスタリングし，クラスタ毎に， ワードの共起構造について分析する. そして，その結果 を北海道新幹線開業前後で比較し, 人々の関心構造の変 化について明らかにする。

\section{(1) ユーザの類型化}

分析対象としたユーザの中には, 新幹線開業後に対象 地域である函館エリアに関心や期待が大きくなったユー ザだけではなく，そもそも無関心なユーザ，さらには開 業後に関心が小さくなったユーザなどがいると思われる。 そこで，全地域・拠点ワードを「函館」「他道内」「道 外」の3つのエリアで区分し，ユーザ毎にこれらの発生 増減数（2016 年一2015 年）を求め, その類似性でクラ スリングした. また，「函館」は検索ワードとして用い た函館エリアを中心とする道南・道央地域の 33 市町村 およびそれらの地域内の拠点のワードで構成される.

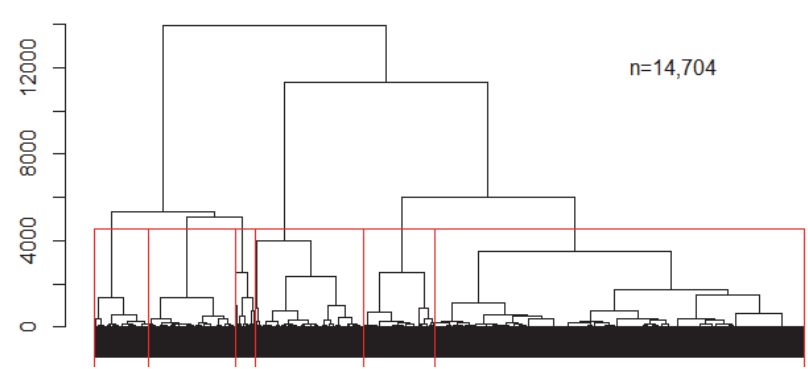

図-5 デンドログラム

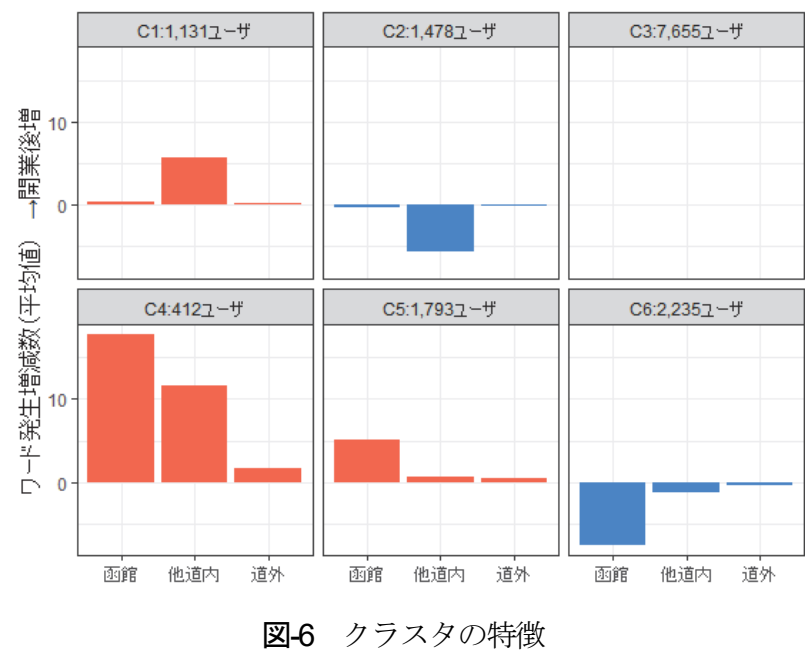

「他道内」はそれ以外の道内の市町村名・拠点ワードで あり，「道外」は道外の都道府県ワードとした。

なお，Twitter を含む SNS では，特に同じ関心や情報 を持つユーザ間でのコメント閲覧やコミュニケーション が頻繁に行われるため, 他人のツイートが発言自体やそ の内容に与える影響は小さくない. 図-2 に示したよう に, 開業後にツイート全体が増加していることから，他 人の動向がユーザ個々の各ワード発生量に少なからず影 響していると思われる。しかしながら，このような関心 や情報の拡散 15)を SNS の一つの特長と捉え, その影響 を含めた上でユーザの類型化を行った.

ユーザ毎に，上記の 3 エリアに関するワードの発生増 減数を求め, 正規化処理を行った後, クラスター分析

（Ward 法）を適用した. 得られたデンドログラムを図5 に示す.ここでは，各クラスタの特徵をつかむこと， デンドログラムの分岐が分かりやすいことから, 同図に 示すように全ユーザを 6 つのクラスター（C1～C6） に 類型化した. 各クラスターのワード発生増減数の平均值 を図6に示す.

C1 は，「他道内」のワードが開業後に増加しており， 道南・道央地域よりもその先にある道内地域・拠点への 関心が増加したユーザと言える. C2 は，その逆であり， このユーザは, 開業前は道内地域・拠点に関心があった が，開業後に何らかの影響により関心が低下したと思わ れる. C3 は, どのワードも開業前後で増減がなく, 関 


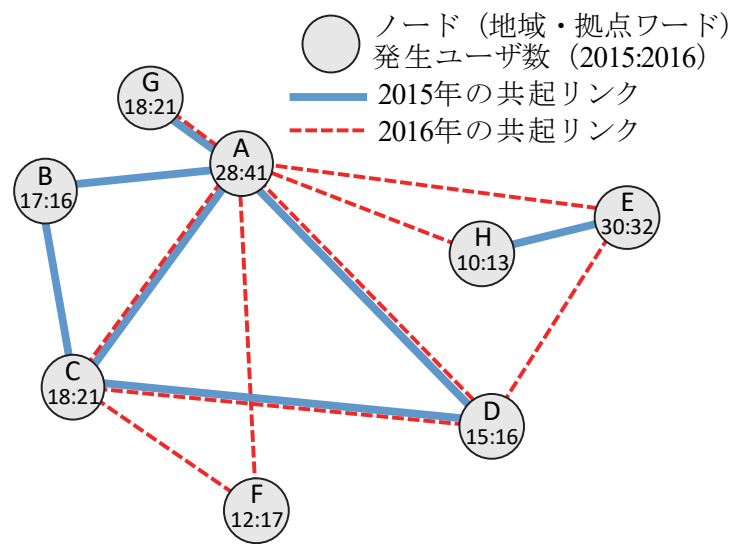

図-7 地域・拠点ワードの共起構造（例）

心の変化が小さい，C4 は，「函館」と「他道内」が増 加しており，北海道新幹線開業により北海道全体一の期 待が高まっているユーザーと言える．C5 は，「函館」 の久が増加しており，特に函館エリアや近隣の道央地域 への関心が増加したユーザと考えられる．C6 は，その 逆であり，開業後に関心が低下ユーザである.

以下では，これらのクラスタ別に地域・拠点ワードの 共起構造について分析するが, サンプル数の確保からク ラスタの統合を行い，以下の3つのユーザ層に区分した. 北海道新幹線開業後に北海道および道内拠点への関心が 増加したと考えられる $\mathrm{Cl} ， \mathrm{C} 4 ， \mathrm{C} 5$ は「関心増加層 (3,336 ユーザ)」，逆に関心が低下した C2 と C6 は 「関心低下層（3,713 ユーザ）」とし, 残りの関心の変 化が少ないC3 は「無変化層（7,655ユーザ）」とした.

\section{（2）北海道新幹線開業後のワード共起構造の変化}

各ユーザは，対象期間内に複数の地域や拠点に関心 を持ち，北海道新幹線開業後にこの関心先の関連性が変 化していると考えられる. そこで，以下に示す方法で共 起するワードをネットワークとして捉え，上記の 3 つの 層の共起構造について比較を行う.

まず，各層のユーザ数が異なると比較が困難となる ため，それぞれ 3,000 名をランダムサンプリングし，ユ 一ザ数を統一した．次に，ユーザ毎に，期間中に発生し た複数の地域拠点ワードを全組み合わせで結び，共起マ トリクスを作成した．図-7 はそれを可視化した例であ る. 2 対のワード (ノード) を結ぶ 1 本のリンクには, ユーザ数の情報を持っており, このユーザ数が 10 未満 のリンクはノイズと考え，分析から除外寸る. 同図の場 合は，D を発生させたユーザ数が 2015 年，2016 年にそ れぞれ 15 名，16名であり，2015年では 10 人以上のユー ザによって A，C と共にコメントされている．2016年に は，さらに Eが共にコメントされるようになり，Dから 出るリンク数は 2 本から 3 本に増える. このようにノー
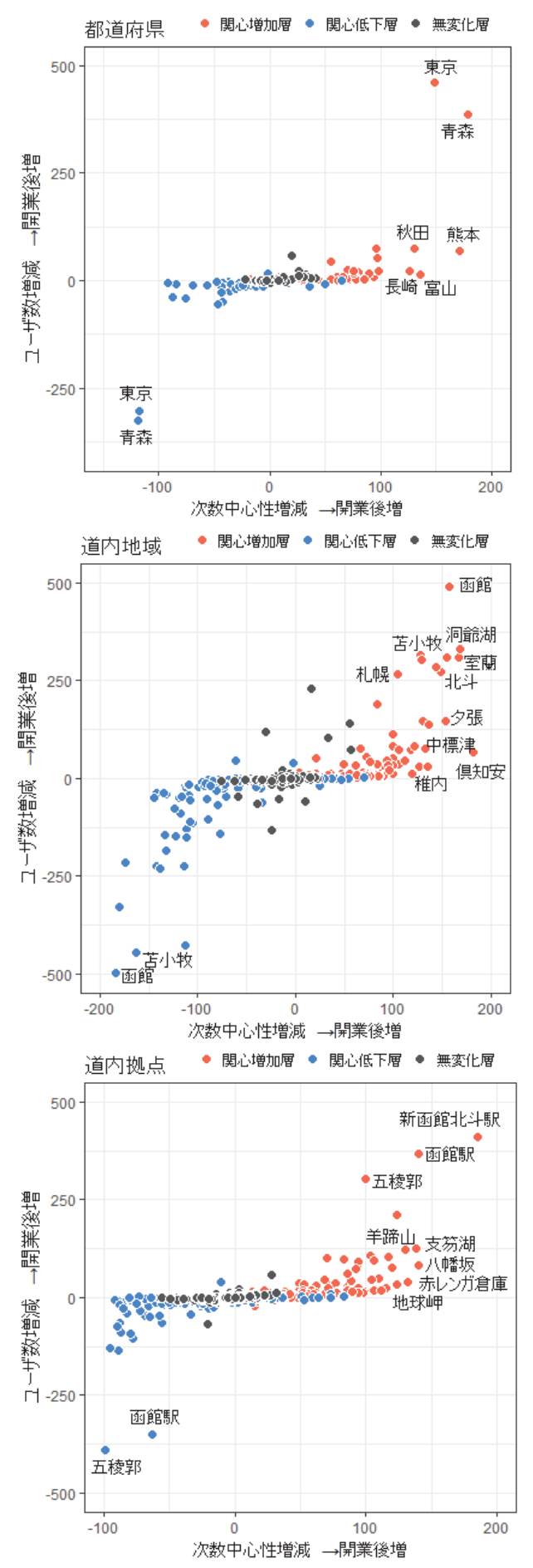

図-8 各ユーザ層の次数中心性増減数とユーザ数増減

ドから出るリンク数は, 次数中心性といい, 当該ノード の居所的な中心性を表寸指標として用いられる. 本研究 では, この次数中心性の時間変化, 差分に着目し, 北海 道新幹線開業後に, どのような地域・拠点が他の多くと 共起されるようになるのかを明らかにする.

上記の方法で求めた次数中心性と第 3 章で用いたユー ザ数について，それぞれ北海道新幹線開業前後の差分 （2016 年一2015 年）を求め, 両者の関係をプロットし た（図-8）。関心増加層では, ユーザ数の増減は小さい 
が, 次数中心性の変化は大きい. 関心低下層は, その逆 を示すものの, 関心増加層よりも変化は小さい. 図-3 において，函館地域ワードの開業後のユーザ数増加が見 られなかった原因は，この関心低下層が減少側に作用し たことによるものと考えられる，無変化層については， 両指標の増減が小さく, 特に特徵は見られない.

以下では，関心増加層に着目して両指標の関係から考 察を加える. 都道府県レベルでは，「東京」や「青森」 が開業後に大きく増加している．これに対し，「秋田」 や「熊本」などは, ユーザ数の増加は小さいが, 次数中 心性の増加が大きい，道内市町村レベルでは，「函館」 や「苫小牧」，「札幌」などの主要な都市のユーザ数が 大きく増加する一方，「夕張」や「中標津」，「俱知 安」などの函館エリア以外の遠方の地域では, 特に, 次 数中心性が増加した. 図-7 より解説すると, 例えば,

「俱知安」は，同図 D のように，開業前後で発生させ たユーザ数はほぼ変わらないが, 開業後に他のワード

（同図で言えば E）とともに発生させたユーザが 10 人 以上存在し, 次数中心性が増加したことが分かる. 北海 道新幹線開業によって, 函館エリアだけではなく, 道内 における様々な地域にも関心が向けられ，これらの地域 が他の多くの地域とともに関心が持たれるようになった と推測される.ただし，このような SNS データだけで は推測の範囲に留まることから, アンケート調査などの 補足的なデータから根拠を補強する必要である.これに ついは, 今後, 函館周辺エリアを対象に実施し, 分析 を行う予定である。

道内拠点レベルにおいては，「新函館北斗駅」や「五 稜郭」などの函館エリアの主要なスポットでユーザ数が 増加した. 一方,「八幡坂」,「赤レンガ倉庫」などの 函館エリアの観光スポットの他，「羊蹄山」や「地球 岬」など遠方の観光地の次数中心性が増加している.こ れらは，他の多くのワードと共に関心が持たれるように なり，ユーザ（関心増加層）が観光先として連想する拠 点の幅が広がったと言える.コメントそのものの意味を 詳細に調べる必要があるが，上記のような地域・拠点ワ ードの関連性から新たなニーズを割り出し, 周遊コース を提案することが可能と思われる，ただし，実際に周遊 コースを提案するためには，移動，滞在にかかる時間や コストなども考慮する必要がある，今後は，本研究で得 られた拠点をマップ上に落とし込み，上記のような考慮 を加えた上で，より具体的な周遊コースの提案方法につ いて検討したい.

\section{（3） ワード共起構造と関心増加の関係}

前節において, 北海道新幹線開業前後における次数中 心性の増減がユーザ層で異なることが分かった.このこ とから，開業前（2015年）においてもユーザ層毎に関心

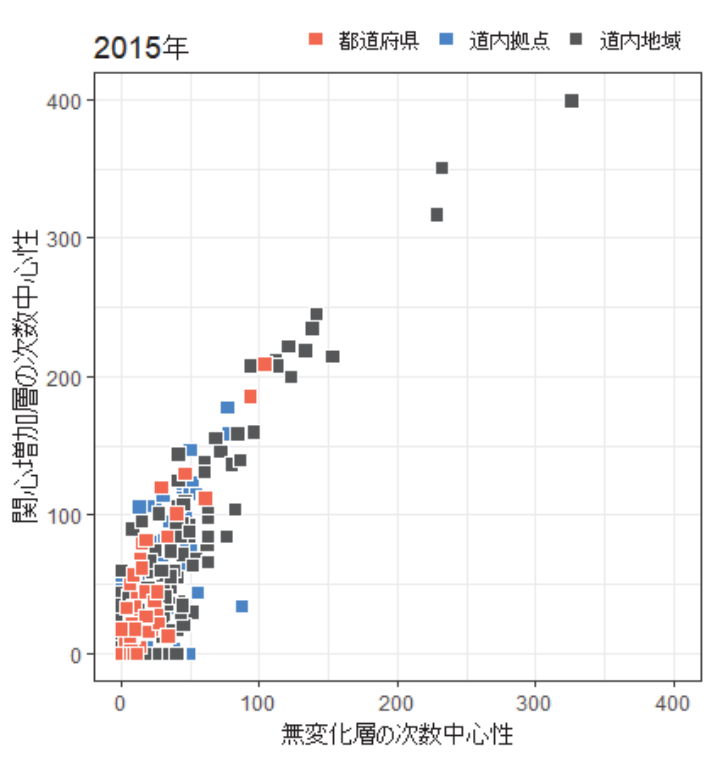

図-9 開業前における次数中心性のユーザ層比較

構造が異なると推測される，そこで，開業前の2015年に おける次数中心性をユーザ層で比較した（図-9）。なお, 関心低下層は, 関心増加層の逆の傾向を示し, 各ワード の特徵を捉えにくくすることから，ここでは，関心低下 層を分析から除外した.

どの空間レベルにおいても, 次数中心性は, 大半のワ ードで関心増加層の方が無変化層に比べて大きいことが 分かる. この関心増加層について, 開業前の次数中心性 と, 開業後のユーザ数増減および炊数中心性増減との関 係を求めたところ，図-10，図-11に示すように，おおよ そではあるが両者の間に正の相関が見られた。これは，

図-7から説明すると，例えば，同図AとCは開業前2015年 の次数中心性がそれぞれ4，3であり，その值が大きいA は開業後2016年になるとユーザ発生数と次数中心性の増 加がCよりも大きくなる，という現象を表している. 次 数中心性は，ユーザ個人が様々なワードを発生させるこ とにより大きくなる．したがって，多くの地域・拠点に コメントするユーザを将来の関心増加層として判別でき れば，そのユーザ集団によるワードの次数中心性から， どの拠点で，関心が増加するのか，他とのつながりが広 がるのかを予測できると思われる。

北海道新幹線に関しては，2030年に札幌延伸が計画さ れており, 計画ルート周辺や関連エリアにおいて観光客 獲得のため, 観光拠点の配置や重点化などの動きが見え 始めているところである。このような規模の大きい都市 施策，交通整備等において，人々の関心構造や将来の変 化を事前に把握することは, 関連地域, 組織において極 めて重要な課題と言えよう。一方, SNSは, 画像や音声 に加え，タグや位置情報など，ますます有用なデータが 蓄積されていくと予想される. 今後, これらのデータや 


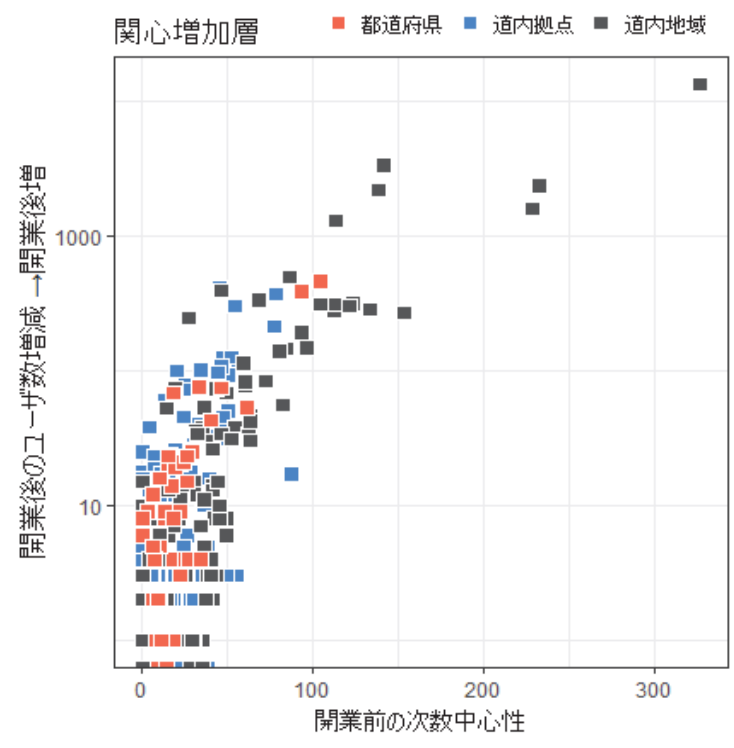

図-10 開業前次数中心性と開業後ユーザ数増減

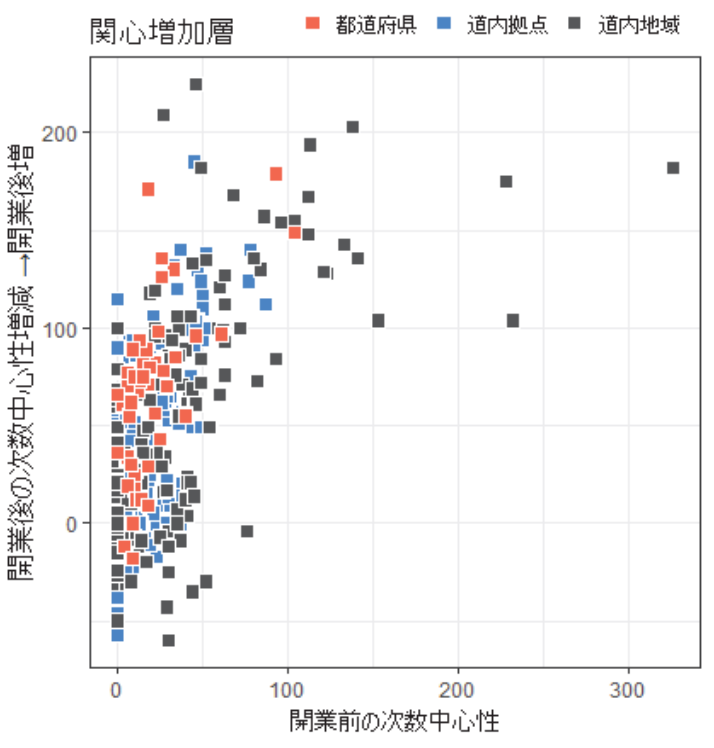

図-11 開業前次数中心性と開業後次数中心性増減

こと，開業後に関心先が大きく広がることを示した。

- 開業前における次数中心性を関心増加層と無変化層 で比較したところ，多くのワードにおいて関心増加 層の方が大きくなり，さらに，それらは開業後にユ 一ザ数や次数中心性が増加するワードとなる傾向が 示された.これは, ワードの共起構造から, 将来に おける対象地域への関心の増加や関心先のつながり の拡大を予測できることを示唆している.

本研究では，2時点の差分という量的な指標からSNS 上における関心構造の比較を行った. 今後は, コメント データについて，形態素解析等のテキストマイニングを 適用して，言葉の意味を考慮した上で，地域・拠点ワ一 ドの質的な分析を行い，具体的な周遊ルートの提案や， 重視，連携すべき観光拠点の抽出につなげたい. 一方で， SNSでコメントするユーザは, 関心に偏りがあり, 人々 の代表にはならないなどの指摘がある. しかし, 近年で は，ネット上のコメントや写真，ロコミなどから注目さ れる観光拠点もあり，人々の関心のつながりから新たな 関心先が生まれるケースも少なくはない. 本研究のよう に，ネット上にある膨大なデータからユーザを類型化し， ワードの共起構造などを分析して, 観光拠点のつながり やそれらに関心を持つユーザを特定することは，ネット 時代における観光戦略において極めて重要と考える. 北 海道新幹線のように，大型の施策，交通整備，社会環境 変化等により人々の地域へのまなざし, 関心が大きく変 容するような事例は他にもある. 今後は，それらを対象 に研究を重ね, 関心構造の変化を予測するモデル等, SNS分析の手法論の確立に貢献したい. また, SNSの分 析結果のみでは, 実際の関心構造の変化を根拠付けるこ とは難しいことから，今後は，アンケート調査等を実施 
し，補足的なデータを加えて，本分析手法の信頼性を向 上させる予定である。

謝辞 : 本研究は，Japan Science and Technology Agency (JST), e-ASIA Joint Research Programの助成を受けた。ここに記し て感謝の意を表する.

\section{参考文献}

1) 鈴木祥平，池田拓生，倉田陽平，石川博：Twitter の ユーザプロフィールを用いた観光地の類型化，第 7 回データ工学と情報マネジメント関するフォーラム 最終論文集，A2-1,2015.

2) 佐伯圭介，遠藤雅樹，廣田雅春，倉田陽平，横山昌 平，石川博 : 外国人 Twitter ユーザの観光訪問先の属 性別分析，第 7 回データ工学と情報マネジメント関 するフォーラム最終論文集, C4-3, 2015.

3) 今井悠貴, 寺部慎太郎, 康楠：空間統計手法を適用 したご当地グルメ店舗配置の分析，土木学会論文集 D3 (土木計画学)，Vol. 73, No. 5, pp. I_399-I 405, 2017.

4) 中嶋勇人, 新妻弘崇, 太田学 : 位置情報付きツイー 卜を利用した観光ルート推薦, 情報処理学会研究報 告, Vol. 2013-DBS-158, No. 28，2013.

5) 藤生慎, 高田和幸, 冨田智之, 伊東大輔：ゲリラ豪 雨時の社会現象に関する一考察一twitter を用いた検討 一, 土木計画学研究・講演集 (CD-ROM)， Vol. 49, 論文番号 190, 2014.

6) 榎本甫, 桑野将司, 小池淳司：災害時のソーシャル メディアと行動の関連性分析，土木学会論文集 D3 (土木計画学)，Vol. 70, No. 1,pp. 102-112, 2014.
7) 岡野大輔, 久保田尚, 上野俊司, 花村嗣信 : Twitter を活用した新しいバス情報システムの普及可能性に 関する研究, 土木計画学研究・講演集, Vol. 44, 論 文番号 $163,2011$.

8) 矢野晋哉, 伊藤秀昭, 安田幸司：道路開通に関する ツイッター情報の分析事例, 土木計画学研究・講演 集（CD-ROM），Vol. 48，論文番号 203, 2013.

9) 富永透見, 肥後洋平，谷口守：ネットコンシャスな 拠点計画に関する一考察チェックインスポットに 着目して一，土木計画学研究・講演集（CD-ROM）, Vol. 50, 論文番号 37, 2014.

10）谷口守，星野奈月，富永透見：自治体の観光資源に 対する認識と SNS 上の「話題」とのギャップ分析, 土木計画学研究・講演集 (CD-ROM) , Vol. 50, 論 文番号 35, 2014.

11）谷口守，星野奈月，富永透見：「つぶやき」から見 る都市についての一考察一都市名に着目して一, 都 市計画学論文集, Vol. 49, No. 3, pp. 939-944, 2014.

12) 山本岳, 浅田拓海, 鈴木貴文, 有村幹治 : Twitter デ ータを用いた地域拠点ワードの共起パターン分析, 土木計画学研究・講演集 (CD-ROM) , Vol. 53, CDROM, pp. 1444-1448, 2016.

13）総務省 IICP 情報通信政策研究所: 平成 28 年度情報通 信メディアの利用時間と情報行動に関する調査一ア ンケート調査集計表一, 2016.

14) 鳥海不二夫 : Twitter 上のビッグデータ収集と分析, 組織化学, Vol. 48, No. 4, pp. 47-59, 2015.

15) 総務省: 平成 27 年版情報通信白書一第 2 部 ICT が拓 く未来社会一, 2017.

(2018. 2. 23 受付)

\section{A CHANGE OF INTEREST PATTERN IN SNS AFTER OPENING THE HOKKAIDO SHINKANSEN}

\section{Takumi ASADA, Takafumi SUZUKI and Mikiharu ARIMURA}

In this study, we analyzed the increase in the number of regional / spot words in SNS and their relevance by using Twitter data before and after the opening of the Hokkaido Shinkansen. And we revealed the change of interest pattern. First of all, we calculated the number of occurrences individually for each word and extracted regions and tourist spots where interest increased after opening. Next, based on the similarity of the occurrence pattern of word, users were categorized into the interest increase type, interest reduction type, and unchanged type. Finally, co-occurrence structure of regional / spot word is analyzed for each user type, and the relevance of interest is quantitatively evaluated from degree centrality index. As a result, several words which were difficult to extract with individual number of occurrences were particularly noticeable in the interest increase type. In addition, it revealed that users' interests greatly expand after opening. 